\title{
Residual Stress Distribution in Friction Stir Welded ODS Steel Measured by Neutron Diffraction
}

DOI:

10.1016/j.jmatprotec.2017.03.013

\section{Document Version}

Accepted author manuscript

Link to publication record in Manchester Research Explorer

\section{Citation for published version (APA):}

Dawson, H., Serrano, M., Cater, S., Wady, P., Pirling, T., \& Jimenez-Melero, E. (2017). Residual Stress

Distribution in Friction Stir Welded ODS Steel Measured by Neutron Diffraction. Journal of Materials Processing Technology, 246, 305-312. https://doi.org/10.1016/j.jmatprotec.2017.03.013

\section{Published in:}

Journal of Materials Processing Technology

\section{Citing this paper}

Please note that where the full-text provided on Manchester Research Explorer is the Author Accepted Manuscript or Proof version this may differ from the final Published version. If citing, it is advised that you check and use the publisher's definitive version.

\section{General rights}

Copyright and moral rights for the publications made accessible in the Research Explorer are retained by the authors and/or other copyright owners and it is a condition of accessing publications that users recognise and abide by the legal requirements associated with these rights.

\section{Takedown policy}

If you believe that this document breaches copyright please refer to the University of Manchester's Takedown Procedures [http://man.ac.uk/04Y6Bo] or contact uml.scholarlycommunications@manchester.ac.uk providing relevant details, so we can investigate your claim.

\section{OPEN ACCESS}




\section{Residual Stress Distribution in Friction Stir Welded ODS Steel}

\section{Measured by Neutron Diffraction}

H. Dawson ${ }^{\mathrm{a},{ }^{*}}$, M.Serrano ${ }^{\mathrm{b}}$, S. Cater ${ }^{\mathrm{c}}$, P. Wady ${ }^{\mathrm{d}}$, T. Pirling $^{\mathrm{e}}$, E. Jimenez-Melero ${ }^{\mathrm{a}}$

${ }^{a}$ School of Materials, University of Manchester, Manchester M13 9PL, United Kingdom

${ }^{b}$ Structural Materials Division, Technology Department, CIEMAT, Avda de la Complutense 40, 28040 Madrid, Spain

${ }^{c}$ Friction and Forge Processes Department, Joining Technologies Group, TWI

Technology Centre (Yorkshire), Advanced Manufacturing Park, Wallis Way, Catcliffe, Rotherham S60 5TZ, United Kingdom

${ }^{d}$ Dalton Cumbrian Facility, University of Manchester, Westlakes Science \& Technology Park, Moor Row, Cumbria, CA24 3HA, United Kingdom

${ }^{e}$ Institut Laue-Langevin, BP 156, rue de Horowitz, 38042 Grenoble Cedex 9, France

\section{Corresponding author $(*)$ :}

University of Manchester

School of Materials

Oxford Road

Manchester

M13 9PL

United Kingdom

Tel.: +447984657227

Email: huwdawson@gmail.com 


\begin{abstract}
The residual stress distributions in oxide dispersion-strengthened steel plates, joined by Friction Stir Welding, have been mapped using neutron diffraction. The measured stress maps were interpreted in terms of the temperature profiles measured for welds using three different tool traverse speeds. The largest peak longitudinal tensile stresses, 1200 MPa, were found in the weld produced using the fastest tool traverse speed, and corresponds to relatively high cooling rates. A reduction in tool traverse speed yields a significant decrease in tensile residual stresses in the thermo-mechanically affected zone of the welds, but also causes higher peak temperatures during welding. The transverse residual stresses were not found to be affected by the tool traverse speed and were significantly lower in magnitude than the longitudinal stresses. Additionally, the torque profiles measured during welding increased with the amount of material stirred and therefore correlated with the width of the thermomechanically affected zone of the welds.
\end{abstract}

Keywords: Friction Stir Welding, Oxide Dispersed-Strengthened Steel, Residual Stress Analysis, Neutron diffraction 


\section{Introduction}

Oxide Dispersion-Strengthened (ODS) steels are one of the most promising structural material candidates for the cladding of Gen IV fission reactors and for first-wall components in magnetically-confined fusion reactors, discussed in a review by Zinkle and Snead (2014). ODS steels offer an outstanding combination of high-temperature strength and creep resistance. These properties are largely dependent on the presence of a fine homogeneous dispersion of $\mathrm{Y}(\mathrm{Al}, \mathrm{Ti})$ oxide nano-particles throughout the matrix. ODS steels also present a high resistance to void and helium bubble formation induced by radiation. These properties stem largely from the high density of particle/matrix interfaces that act as preferential trapping sites for trapping radiation-induced lattice defects and helium atoms, see Brodrick et al. (2014) and Odette et al. (2008), and also as effective obstacles for dislocation movement, providing excellent high temperature strength and creep resistance.

Despite these beneficial properties for the realization of next generation nuclear reactors, the joining of ODS steel components still remains a technological challenge limiting their potential use in the nuclear industry, since the use of standard joining techniques will cause the ODS steel to melt. As a consequence the oxide nano-dispersoids would either agglomerate or dissolve in the matrix, creating a welded region with inferior strength and radiation resistance as compared to the base material. Friction Stir Welding (FSW) is a solid state technique that is potentially able to join ODS steel plates without melting the material, and therefore causing minimal disruption to the nano-oxide dispersion. FSW relies on the local deformation and localized heating caused by the welding tool, as it rotates and advances along the weld line between the two metallic plates to be joined together, see Fig. 1a from Su et al. (2013).

Unfortunately, this welding process can cause significant residual stresses that may detrimentally affect the properties of the material, such as fatigue strength, toughness and 
corrosion resistance of the material and could consequently lead to catastrophic failure of ODS reactor components close to the welding zone during service operations. The impact of residual stresses on the properties of materials is discussed at greater length in Totten (2002) and in Williams and Steuwer (2009). Current experimental data and knowledge about the generation of residual stresses resulting from FSW is very limited in ODS steels, and steels in general according to Kumar et al. (2014), and does not allow to link the welding parameters to the residual stresses. This hinders the application of FSW as joining technique in ODS steel components for future nuclear reactors. This paper aims to assess the residual stresses created in ODS steel butt welds, and the effect of changing the traverse speed of the welding tool, by the use of neutron diffraction.

\section{Experimental}

\subsection{Starting ODS steel material}

MA956 is a fully ferritic ODS steel that contains high levels of $\mathrm{Cr}$ and $\mathrm{Al}$ for corrosion and oxidation resistance, see Table 1. The material was produced by Special Metals, UK, and was provided in the form of a $10 \mathrm{~mm}$ thick plate with a final recrystallization annealing treatment at $1320^{\circ} \mathrm{C}$ for $1 \mathrm{~h}$. Despite this high temperature anneal, the material mostly retained its fine microstructure in the centre line of the plate, with typically $1-2 \mu \mathrm{m}$ ferritic grains elongated along the extrusion axis, while the plate surface underwent abnormal grain growth, see Fig. 1a and b. More detail about the microstructure of the MA956 plates can be seen in Dawson et al. (2017). Texture measurements were made on a D8 Bruker X-ray Diffractometer with a collimated cobalt source, and the data analysis was carried out using the MTEX software, Bachmann et al. (2010). The plate showed a strong (100)<110> rolling texture, Fig. 1c. These plates were cut in half through thickness by electrical discharge machining to produce nominally $4 \mathrm{~mm}$ thick plates. 


\begin{tabular}{|c|c|c|c|c|c|c|c|c|c|c|c|c|c|c|c|}
\hline $\mathrm{Cr}$ & $\mathrm{Al}$ & $\mathrm{Y}_{2} \mathrm{O}_{3}$ & $\mathrm{P}$ & $\mathrm{Ti}$ & $\mathrm{O}$ & $\mathrm{C}$ & $\mathrm{Mn}$ & $\mathrm{Si}$ & $\mathrm{Mo}$ & $\mathrm{Ni}$ & $\mathrm{Co}$ & $\mathrm{N}$ & $\mathrm{Cu}$ & $\mathrm{S}$ & $\mathrm{Fe}$ \\
\hline 19.97 & 4.44 & 0.53 & 0.53 & 0.33 & 0.21 & 0.15 & 0.11 & 0.05 & $<0.05$ & 0.04 & 0.03 & 0.022 & 0.009 & 0.004 & bal. \\
\hline
\end{tabular}

Table 1. Chemical composition of the studied MA956 ODS steel (wt\%).
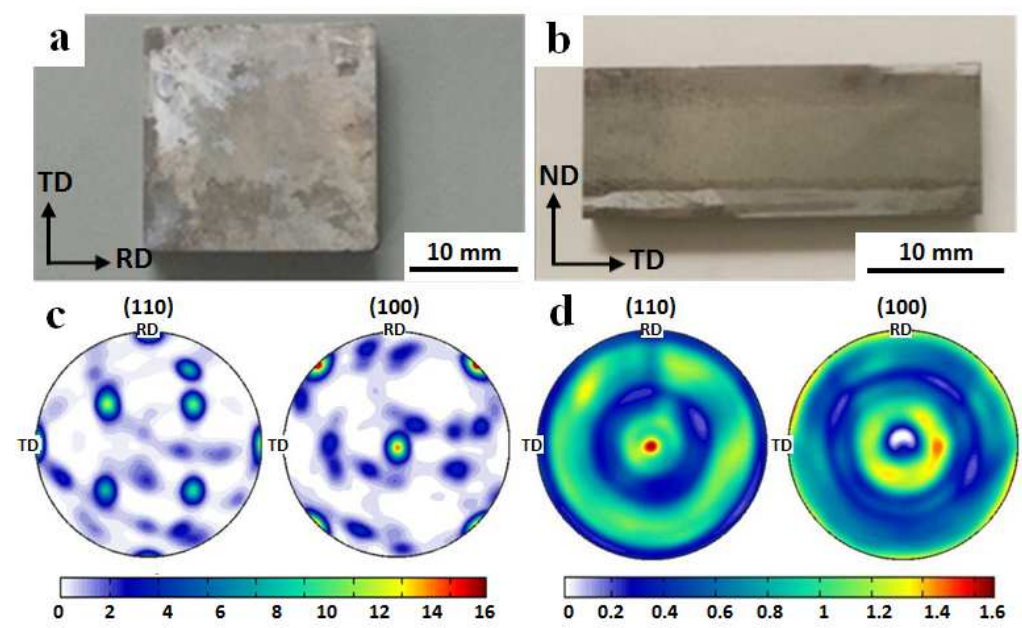

Fig. 1. (a)-(b) Optical images of the base material along the LD/TD and ND/TD planes respectively; (110) and (100) pole figures of the (c) base material in the fine-grained centre line of the plate and (d) in the thermo-mechanical affected zone of the ODS steel welds. The scale is in multiples of random distribution. Data in (a) and (b) taken from Dawson et al. (2017).

\subsection{Friction stir welding of $O D S$ steel}

Butt welds were made on these plates using an MTI RM-2 Precision Spindle FSW machine in the presence of an argon shielding gas, using depth control and a steel backing plate. Due to the non-uniform distribution in ferrite grain size through the thickness of the plates, the butt welds were carried out with the coarse grains at the top of the workpiece. The tool used for all the welds was a Q70 grade Megastir polycrystalline cubic boron nitride (PCBN) tool with a shoulder diameter of $25 \mathrm{~mm}$ and pin length of $3 \mathrm{~mm}$. The tool had a dwell time of $35 \mathrm{~s}$ after being plunged and before traversing along the welding line, and $25 \mathrm{~s}$ before exiting the welded plates. A downforce of $25 \mathrm{kN}$ and a tool rotation speed of 200 rotations per minute were used. Three welds with varying tool traverse speed were produced: 70, 95 and $120 \mathrm{~mm} / \mathrm{min}$. Internal temperatures during welding were measured by embedding type $\mathrm{k}$ thermocouples with Alloy 600 sheath material into the plates, by boring $1 \mathrm{~mm}$ diameter holes 
by electric discharge machining from the edge of the plate. Fig. 2 shows the position of all of the thermocouples in the three welds. For Welds 2 and 3 the thermocouples holes were bored right up to the joint line, $2 \mathrm{~mm}$ from the top surface of the plate. For Weld 1 the holes were also $2 \mathrm{~mm}$ from the top surface of the plate but the position of the thermocouples were gradually staggered back from the centre of the joint line in $1 \mathrm{~mm}$ steps, starting from the exit hole end. The thermocouples were not positioned closer than $30 \mathrm{~mm}$ to each other.

Ultrasound testing was used to check the position and survival of the thermocouples of Weld 1, see Fig. 2b. The macroscopic structure of the weld cross sections was revealed by etching with a solution containing 15 vol. $\% \mathrm{HCl}$ and 3 vol. $\% \mathrm{HNO}_{3}$. The images were taken using a Keyence VK-X200K 3D Laser Scanning Microscope.
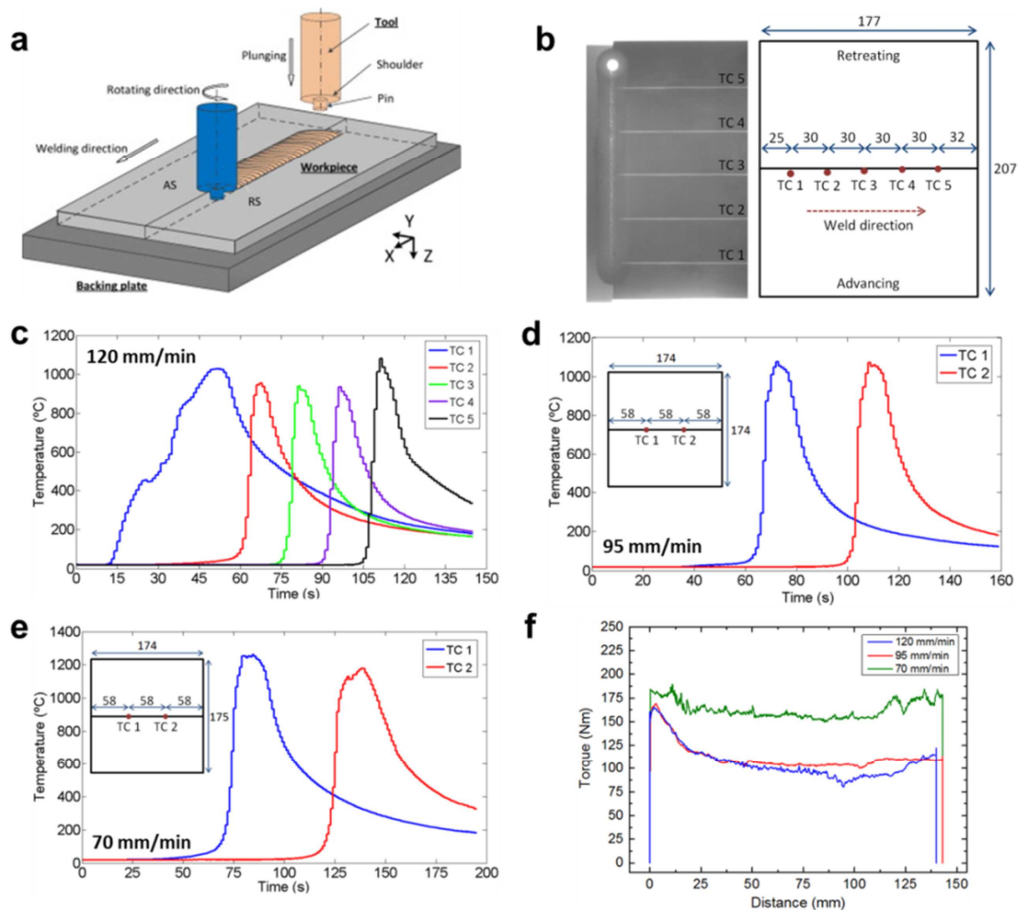

Fig. 2. (a) Schematic diagram of the friction stir welding process, adapted from Su et al. (2013); (b) ultrasound image showing the bored thermocouple holes and diagram of thermocouple positions for Weld 1; (c)-(e) temperature profiles during FSW for the three welds; (f) torque measured during welding. Lengths are in units of $\mathrm{mm}$.

\subsection{Residual stress determination by neutron diffraction}


Neutron diffraction is a suitable technique to probe residual stresses distributions in engineering alloys by measuring the relative change in the scattering angle, $2 \theta$, as compared to the scattering angle from an unstressed state in the sample, $2 \theta_{0}$. The scattering angles depend on the lattice spacing of the material, according to Bragg's Law, and therefore the lattice itself can act as an effective strain gauge. Residual stresses measurements were performed at the SALSA diffractometer of the Institut Laue-Langevin (ILL) (Grenoble, France), using a monochromatic neutron beam with a wavelength of $\lambda=1.64 \AA$. The gauge volume used was a cuboid with dimensions $0.6 \times 0.6 \times 2 \mathrm{~mm}^{3}$. The perpendicular bisectors of the square faces, lengths $0.85 \mathrm{~mm}$, were aligned parallel to the transverse $(y)$ and normal $(z)$ directions, while the depth of the cuboid ran parallel to the welding direction $(x)$. The main components of the SALSA diffractometer are shown in Fig. 3.

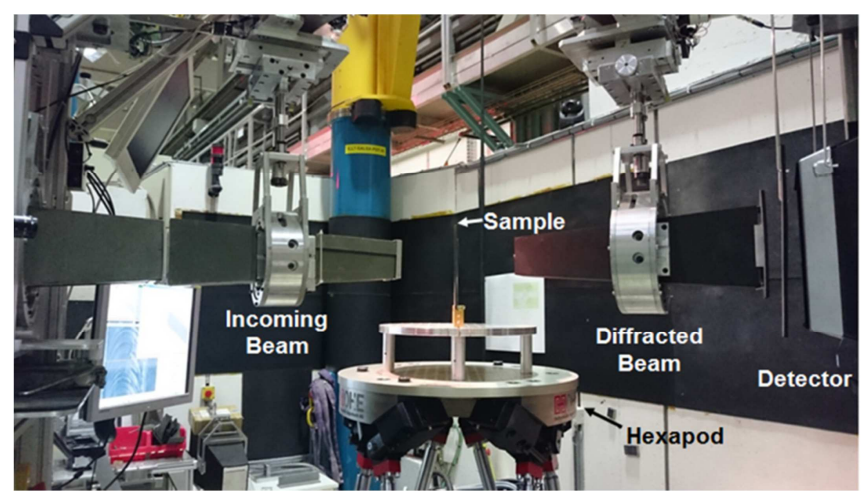

Fig. 3. Main components of the SALSA diffractometer at the ILL, used during the neutron diffraction experiment to obtain the residual stress maps of ODS steel welds.

The welds were placed on the hexapod sample manipulator, which is able to move with high precision in six axes, and therefore maintain accurate alignment for all measured sample positions, see Pirling et al. (2006). The measurements were taken at five selected depths through the thickness of the welds ranging from $0.8 \mathrm{~mm}$ to $3.8 \mathrm{~mm}$ in steps of $0.6 \mathrm{~mm}$, in order to avoid potential surface effects on the residual stress determination. For Welds 1 and 3 , the scanned position was at 70 and $87 \mathrm{~mm}$ from the edge of the plate on the tool entry side, respectively. Weld 2 was measured at three different locations along the weld; 35,87 
and $135 \mathrm{~mm}$ from the edge of the plate on the tool entry side. The measured scattering angle at the selected positions in the welds was used to calculate the lattice strains:

$$
\varepsilon_{i i}=\frac{d_{\{110\}}-d_{0,\{110\}}}{d_{0,\{110\}}}=\frac{\sin \theta_{0,\{110\}}}{\sin \theta_{\{110\}}}-1
$$

where $\mathcal{E}_{i i}$ denotes the lattice strain, and $d$ represents the lattice spacing at a given weld position and $d_{0}$ the reference unstressed lattice spacing. The unstressed position in the sample was characterized to be the average value of the scattering angle of several points, 70 or $80 \mathrm{~mm}$ away from weld centre on the advancing side of Weld 1. The strains of the plates were measured in the longitudinal, transverse and normal directions, represented by $i=x, y$ and $z$ respectively. Due to the relatively strong texture in the base material, only the strains in the $\{110\}$ lattice planes were measured. The stresses along the three principal directions in the material were calculated using the measured strains according to:

$$
\sigma_{i}=\frac{E_{\{110\}}}{1+v_{\{110\}}}\left[\varepsilon_{i}+\frac{v_{\{110\}}}{1-2 v_{\{110\}}}\left(\varepsilon_{x}+\varepsilon_{y}+\varepsilon_{z}\right)\right]
$$

where the Young's Modulus $\mathrm{E}_{110}=224.7 \mathrm{GPa}$, and the Poisson's ratio $v_{110}=0.28$. The values were used by Mathon et al. (2009) on a similar ODS steel, PM2000, and were originally based on the model developed by Kröner (1961) for non-textured bcc iron. The strong texture also meant that no $\{110\}$ diffracted intensity could be detected when probing the normal direction in the base material. However, the microstructure in the thermomechanically affected zone (TMAZ) has a near random texture, see Fig.1d, so it was possible to detect $\{110\}$ diffracted intensity along the normal direction in this region. The thickness of the welded plates was relatively small, and therefore the normal stresses can be approximated as zero, $\sigma_{\mathrm{z}} \approx 0$, described further in Hutchings et al. (2005). The normal strains were therefore determined using the equation:

$$
\varepsilon_{z}=\left(\varepsilon_{x}+\varepsilon_{y}\right) v_{\{110\}} /\left(v_{\{110\}}-1\right)
$$

\section{Results and Discussion}




\subsection{Friction stir welding parameters}

Table 2 contains the characteristic values of the main friction stir welding parameters in the steady state regime. Fig. 3 displays the measured temperature and torque profiles for the three values of the tool traverse speed, together with a schematic diagram of the friction stir welding process. The thermocouple readings in the three welds revealed a relatively uniform temperature during the steady state regime during welding. The peak temperatures during welding increased with decreasing traverse speed. This is to be expected as the heat input $(H I)$ is taken as the ratio of the rotational speed $(\omega)$ to the traverse speed $(v), H I=\omega / v$. Thermocouples 1 and 5 in Weld 1 were placed close to the entry and exit positions of the tool, respectively. Due to the dwell times at these positions, the temperature reached is significantly higher than at the intermediate thermocouple positions.

\begin{tabular}{|c|c|c|c|c|c|c|c|}
\hline $\begin{array}{c}\text { Weld } \\
\text { No. }\end{array}$ & $\begin{array}{c}\text { Traverse } \\
\text { Speed } \\
(\mathrm{mm} / \mathrm{min})\end{array}$ & $\begin{array}{c}\text { Peak } \\
\text { Temp. } \\
\left({ }^{\circ} \mathrm{C}\right)\end{array}$ & $\begin{array}{c}\text { Average } \\
\text { cooling rate } \\
\left({ }^{\circ} \mathrm{C} / \mathrm{s}\right)\end{array}$ & $\begin{array}{c}\text { Time above } \\
400^{\circ} \mathrm{C} \\
(\mathrm{s})\end{array}$ & $\begin{array}{c}\text { Average } \\
\text { Torque } \\
(\mathrm{Nm})\end{array}$ & $\begin{array}{c}\text { Peak Longitudinal } \\
\text { Tensile Stress } \\
(\mathrm{MPa})\end{array}$ & $\begin{array}{c}\text { Peak Transverse } \\
\text { Tensile Stress } \\
(\mathrm{MPa})\end{array}$ \\
\hline 1 & 120 & 943 & 36 & 15 & 83 & 1207 & 728 \\
\hline 2 & 95 & 1074 & 58 & 18 & 88 & 1189 & 809 \\
\hline 3 & 70 & 1220 & 30 & 41 & 159 & 901 & 770 \\
\hline
\end{tabular}

Table 2. Friction stir welding parameters in the steady state regime, together with the peak tensile residual stress along the longitudinal and traverse directions for the three ODS steel welds produced in this study. The average cooling rate has been determined between the peak temperature and $400^{\circ} \mathrm{C}$. Weld 1 used a mean value of only thermocouples $2-4$ in the calculation. Weld 2 and 3 used a mean value of both thermocouples.

The cooling rates were expected to increase with the traverse speed since the rotating tool, which is essentially the heat source, is further away from the temperature measurement position along the weld line at any specific time during the process. The cooling rates were calculated as the mean value of the rate from peak temperature to $400^{\circ} \mathrm{C}$. A mean value was calculated from thermocouples considered in the steady state section of each weld, i.e. thermocouples 1 and 5 for Weld 1 were not included in the calculation. Weld 3, with the slowest traverse speed of $70 \mathrm{~mm} / \mathrm{min}$, has indeed the slowest cooling rate $\left(30^{\circ} \mathrm{C} / \mathrm{s}\right)$ of the three welds, and corresponds to the highest peak temperature $\left(1220^{\circ} \mathrm{C}\right)$. However, the cooling 
rate of Weld $1\left(36^{\circ} \mathrm{C} / \mathrm{s}\right)$ is slower than that of Weld $2\left(58^{\circ} \mathrm{C} / \mathrm{s}\right)$, despite Weld 1 corresponding to the highest traverse speed in this work. This fact may be partly ascribed to the lower peak temperature in Weld 1 causing a smaller temperature gradient. However, one would expect the distance of the welding tool from the measured position to be the dominant parameter, since the rotating tool is the main source of heat in this process. The time that the weld was above $400^{\circ} \mathrm{C}$, arbitrarily, was approximately 15 seconds for Weld 1 and 18 seconds for Weld 2. The anomaly in the cooling rate at the highest traverse speed of $120 \mathrm{~mm} / \mathrm{min}$ will have originated from the non-negligible difference in the distance between the bottom of the TMAZ and the steel backing plate. For Weld 1, see Fig. 4a, i.e. there is nearly $1 \mathrm{~mm}$ between the base of the TMAZ and the bottom of the workpiece which was in contact with the backing plate also acting as an efficient heat sink. Both Welds 2 and 3 presented a full penetration of the welding tool in the ODS steel plates, see Fig. $4 \mathrm{~b}$ and c. Therefore the TMAZ was in contact with the backing bar in those two welds, causing the heat to be dissipated at a higher rate through the backing plate than for Weld 1. The TMAZ of Weld 1 has a similar depth to the other two welds; however a workpiece of slightly greater thickness was used for Weld 1.
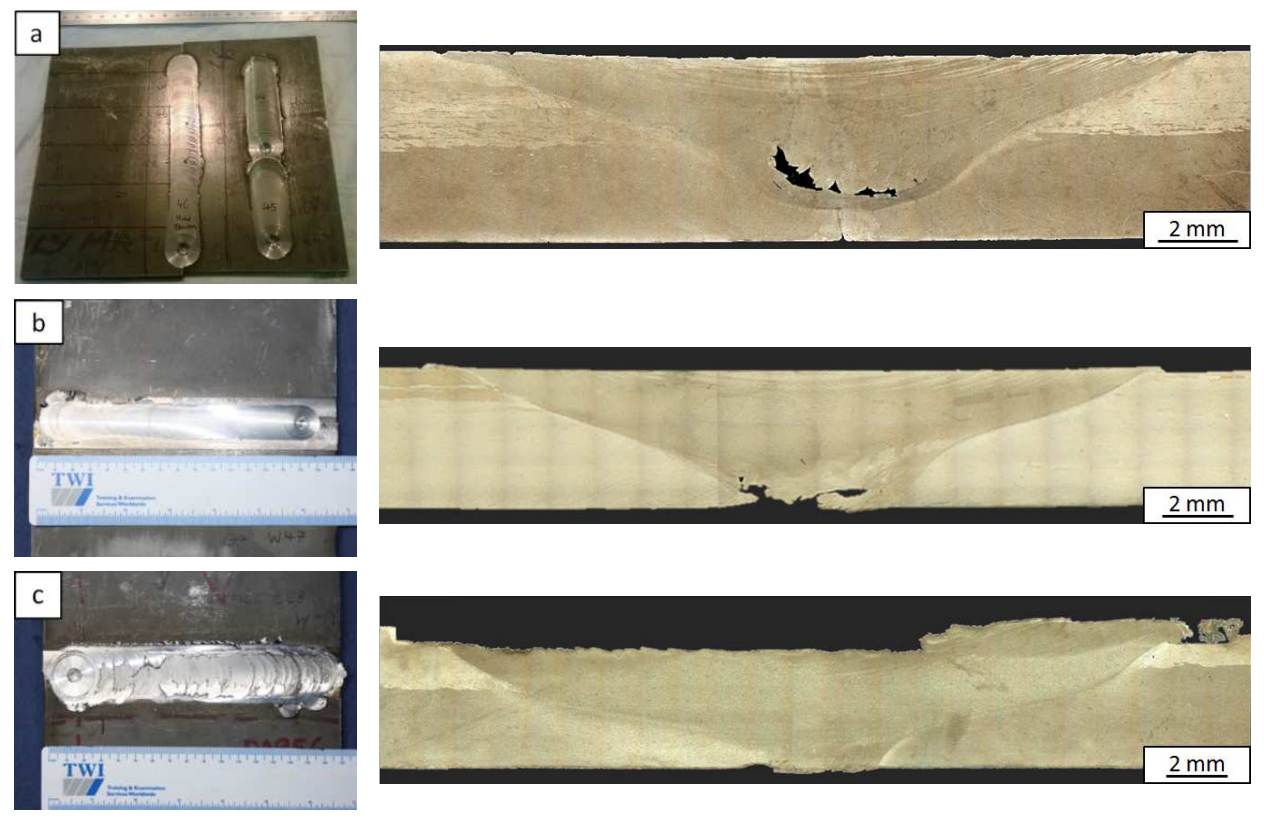
Fig. 4. Optical micrographs of the top view and cross section of the three welds: (a) Weld 1, (b) Weld 2, (c) Weld 3. Advancing side is on right hand side of the cross sections.

The measured torque profile throughout the welding of the three butt welds can be seen in Fig. 3f. The welds have a relatively constant torque throughout the steady state section of the welding process. Furthermore, Welds 1 and 2 have a very similar torque throughout the weld. Several investigations have shown that torque generated during FSW turns out to vary weakly with the traverse speed, as stated in a review on FSW on Al alloys by Çam and Mistikoglu (2014). Su et al. (2013) and Yan et al (2005) both showed an extremely gradual increase in torque with increasing traverse speed. Arora et al. developed a model that closely matched the findings of Yan et al. (2005). For steel, Lienert et al. (2003) also observed no observable trend in torque with traverse speed.

The torque of Weld 3 was measured to be significantly greater than for the other two welds, despite the material becoming more plasticised due to the significantly greater peak temperature achieved during welding. The heat generated during the production of this weld was sufficiently high as to plasticise significantly more material, which means that a larger volume of material was stirred than for Weld 1 or 2 . Moreover, Fig. 4 shows the wider TMAZ of Weld 3 compared to the other two welds. The increased volume of material stirred in Weld 3 will have increased the necessary torque to maintain the rotation speed of the welding tool. The TMAZ's of Weld 1 and 2 seems to be much more comparable in size, and hence the torque measured during welding was similar in both welds.

Work by Mayfield and Sorenson (2010) showed that the torque was not significantly altered by changes to the temperature in the SZ, agreeing with the findings of this study in which Weld 1 and 2 had similar torques despite significantly different internal temperatures.

\subsection{Residual stress distributions}


The residual stress distributions for the three different welds are shown in Fig. 5 along the transverse and longitudinal directions. The measured normal stresses in the welded regions turned out to be relatively small, rarely exceeding a stress of $200 \mathrm{MPa}$. We can expect that the residual stresses outside of the weld will be significantly lower than this; therefore the assumption stated in section 2.3 that the normal stresses are approximately equal to zero seems reasonable. The welds contain relatively large tensile stresses in the TMAZ where the most significant heating occurred during welding, although smaller tensile stresses were observed outside of the TMAZ, particularly on the advancing side towards the top of the workpiece. The distribution of these tensile stresses is approximately symmetric with respect to the welding line, with the highest residual tensile stresses measured close the edge of the TMAZ. Compensating compressive stresses were observed surrounding the TMAZ. The compressive stresses were generally greater on the retreating side and increased towards the bottom of the workpiece. Notably the transverse stresses, though also tensile in nature, are significantly lower than the longitudinal stresses, rarely exceeding the yield stress of the material. Kumar et al. (2014) describes this as being a common trend in friction stir welded alloys. Similar findings have been observed in other friction stir welds for steels, by Steuwer et al. (2012) and Reynolds et al. (2003), in ODS steels by Mathon et al. (2009), and in Al alloys by Peel et al. (2003) and Woo et al. (2006). 


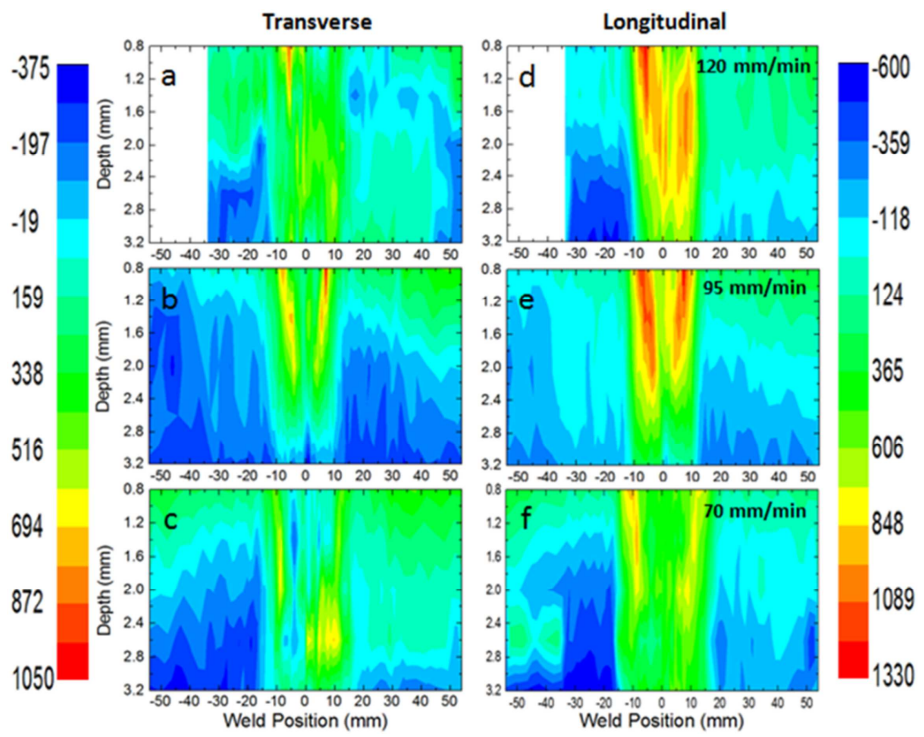

Fig. 5. Residual stress maps of the three ODS steel welds. Stress in units of MPa.

Fig. 6 shows the line scan residual stress data at a depth of $1.4 \mathrm{~mm}$ from the top surface of the three welds. The peak tensile values in the transverse don't seem to be affected significantly by the change in tool traverse speed. The longitudinal residual stresses, however, increase with increasing traverse speed, in agreement with previous reports on friction stir welded engineering alloys, see for instance Peel et al. (2003) or Brewer et al. (2015). It should be stressed that no phase change has been observed following FSW, and therefore this is not considered as a contributor to the residual stress. 

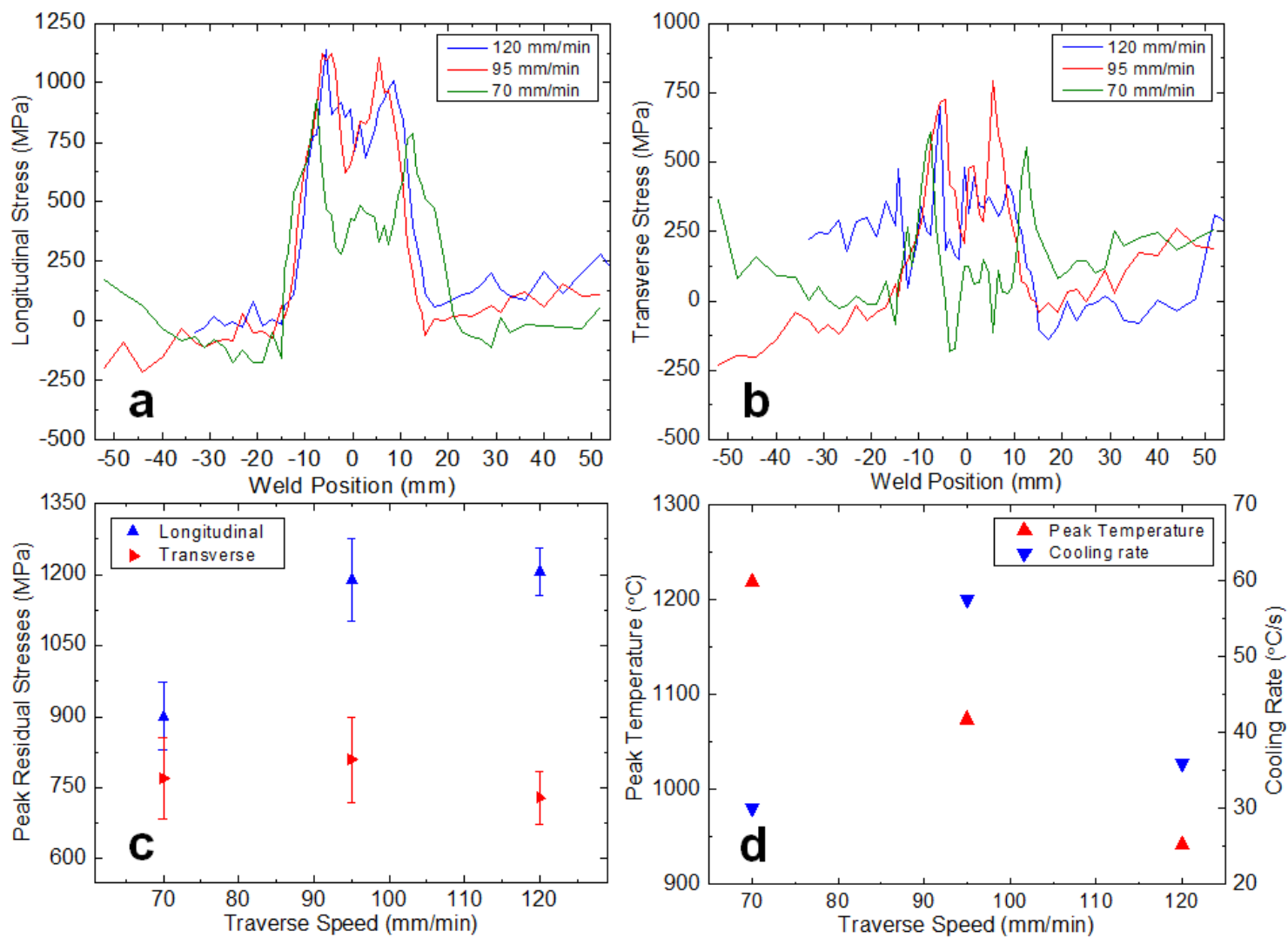

Fig. 6. Line scan residual stress data at a depth of $1.4 \mathrm{~mm}$ from the top surface of the welds, in the (a) longitudinal and (b) transverse orientation; (c) peak tensile residual stress and (d) peak temperature and cooling rate as a function of traverse speed during welding. The peak values are the mean of the greatest 5 values at any 5 measurement locations in each weld.

The dominant factors in determining the magnitude of the residual stresses are likely

to be the peak temperatures during welding and the subsequent cooling rates. The stresses are expected to increase with traversing speed, since there would be a faster associated cooling rate. Welds 1 and 2 had similar cooling rates, and consequently the stresses would have had a similar amount of time to relax, resulting in comparable residual stresses. The cooling rate of Weld 3, with the reduced traverse speed of $70 \mathrm{~mm} / \mathrm{min}$, is significantly lower, and therefore the stresses have more time to relax. The resultant residual stresses are generally lower and spread more evenly through the weld, rarely exceeding the yield stress. Weld 1 and 2 had a much faster cooling rate, and therefore had much larger peak stresses and sharper stress gradients. The residual stresses measured at three selected locations along Weld 2 are reasonably consistent, see Fig. 7. The longitudinal stresses at the extreme locations appear to 
be slightly lower than at the intermediate position. This is likely to be due to their being closer to the entry or exit hole where the tool dwells, which would cause the cooling rate at these locations to be slightly slower than at the intermediate position. The tool, heat input and plate thickness were very stable throughout the weld, as can be seen by the stable torque and temperature profiles in Fig. 3. Therefore the residual stresses are near constant along the weld direction. Positions 1 and 2 also show similar transverse stresses, while somewhat different close to the exit position of the tool.

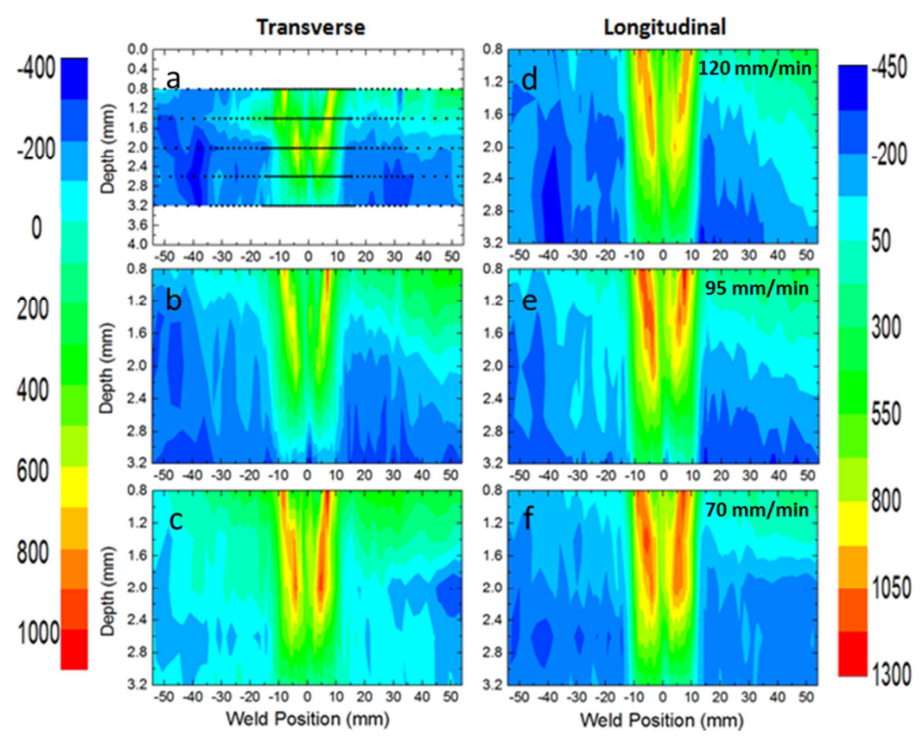

Fig. 7. Residual stress maps of Weld 2, i.e. $95 \mathrm{~mm} / \mathrm{min}$ traverse speed, at the three measured locations. Stress in units of MPa. (a) shows the measurement locations in the TransverseLongitudinal cross section.

These results reveal that FSW can leave significant residual stresses in ODS steels, that should be considered before their implementation in next generation reactors. It is clearly possible to reduce the residual stresses in the TMAZ of the weld by decreasing the traversing speed of the tool; however this generates a higher peak temperature that, if excessively high, may affect the oxide particle stability in the welded zones as shown in Dawson et al. (2017). A post-weld heat treatment may be considered to reduce the residual stresses in the TMAZ of the weld. 


\section{Conclusions}

The residual stresses resulting from the friction stir welding of ODS steel plates has been assessed along with the impact of varying the traverse speed. All of the welds produced in this study retained significant residual stresses after welding, with greater values in the longitudinal orientation than in the transverse. The magnitude of the tensile residual stresses in the TMAZ of the welds depends predominantly on the cooling rate of the welds after the passage of the welding tool, and can therefore be reduced by decreasing the tool traverse speed. However, such a reduction in traverse speed generates higher peak temperatures that, if excessive, may pose a risk for the thermal stability of the nano-oxide particles in the welds. The torque during welding was found to depend predominantly on the amount of material stirred, and is therefore related the width of the TMAZ.

\section{Acknowledgements}

We gratefully acknowledge the financial support of the Engineering and Physical Sciences Research Council UK (EPSRC)(grant number EP/L016273/1) through the Centre for Doctoral Training in Advanced Metallic Systems. We would like to thank CIEMAT in Spain for providing the base material of MA956 ODS steel, and to The Welding Institute (TWI) for providing the welding tools and assistance during friction stir welding. We also acknowledge the Institut Laue-Langevin for the granted beam time for use at the SALSA instrument. 


\section{References}

Arora, A., Nandan, R., Reynolds, A.P. and DebRoy, T., 2009. Torque, power requirement and stir zone geometry in friction stir welding through modeling and experiments. Scripta Mater. 60, pp. 13-16.

Bachmann F., Hielscher R., Schaeben H., 2010. Texture Analysis with MTEX - Free and Open Source Software Toolbox. Solid State Phenom. 160, pp. 63-68.

Brewer, L.N., Bennett, M.S., Baker, B.W., Payzant, E.A. and Sochalski-Kolbus, L.M., 2015. Characterization of residual stress as a function of friction stir welding parameters in oxide dispersion strengthened (ODS) steel MA956. Mater. Sci. Eng. A 647, pp. 313-321.

Brodrick, J., Hepburn, D.J. and Ackland, G.J., 2014. Mechanism for radiation damage resistance in yttrium oxide dispersion strengthened steels. J. Nucl. Mater. 445, pp. 291-297. Çam, G., Mistikoglu, S., 2014. Recent developments in friction stir welding of Alalloys. J. Mater. Eng. Perform. 23, pp. 1936-1953.

Dawson, H., Serrano, M., Cater, S., Iqbal, N., Almásy, L., Tian, Q., Jimenez-Melero, E. 2017. Impact of Friction Stir Welding on the microstructure of ODS steel. J. Nucl. Mater. 486, pp. 129-137.

Hutchings, M.T., Withers, P.J., Holden, T.M. and Lorentzen, T., 2005. Introduction to the characterization of residual stress by neutron diffraction. CRC press.

Kröner, E., 1961. Zur plastischen verformung des vielkristalls. Acta metallurgica, 9(2), pp. $155-161$.

Kumar, N., Mishra, R.S. and Baumann, J.A., 2014. Residual stresses in friction stir welding. Butterworth-Heinemann.

Lienert, T.J., Stellwag Jr., W.L., Grimmett, B.B. and Warke, R.W., 2003. Friction stir welding studies on mild steel. Welding Journal New York, 82(1), pp.1-S. 
Mathon, M.H., Klosek, V., De Carlan, Y., Forest, L., 2009. Study of PM2000 microstructure evolution following FSW process. J. Nucl. Mater. 386, pp. 475-478.

Mayfield, D.W., Sorensen, C.D., 2010. An improved temperature control algorithm for friction stir processing. In 8th International Friction Stir Welding Symposium.

Odette, G.R., Alinger, M.J., Wirth, B.D., 2008. Recent Developments in Irradiation-Resistant Steels. Annu. Rev. Mater. Res. 38, pp. 471-503.

Peel, M., Steuwer, A., Preuss, M., Withers, P.J., 2003. Microstructure, mechanical properties and residual stresses as a function of welding speed in aluminium AA5083 friction stir welds. Acta Mater. 51, pp. 4791-4801.

Pirling, T., Bruno G., Withers, P.J., 2006. SALSA—A new instrument for strain imaging in engineering materials and components. Mater. Sci. Eng. A 437, pp. 137-144.

Reynolds, A.P., Tang, W., Gnaupel-Herold, T., Prask, H., 2003. Structure, properties, and residual stress of 304L stainless steel friction stir welds. Scripta Mater. 48, pp. 1289-1294.

Steuwer, A., Barnes, S.J., Altenkirch, J., Johnson, R., Withers, P.J., 2012. Friction Stir Welding of HSLA-65 Steel: Part II. The Influence of Weld Speed and Tool Material on the Residual Stress Distribution and Tool Wear. Metall. Mater. Trans. A 43, pp. 2356-2365.

Su, H., Wu, C.S., Pittner, A., Rethmeier, M., 2013. Simultaneous measurement of tool torque, traverse force and axial force in friction stir welding. J. Manuf. Process. 15, pp. 495-500. Totten, G.E. ed., 2002. Handbook of residual stress and deformation of steel. ASM International. Williams, S.W., Steuwer, A., 2009. Residual stresses in friction stir welding. Friction stir welding: from basics to applications, pp. 215.

Woo, W., Choo, H., Brown, D.W., Feng, Z. and Liaw, P.K., 2006. Angular distortion and through-thickness residual stress distribution in the friction-stir processed 6061-T6 aluminum alloy. Mater. Sci. Eng. A 437, pp. 64-69. 
Yan, J.H., Sutton, M.A., Reynolds, A.P., 2005. Science and Technology of Welding and Joining. 10 (6), pp. 725-736.

Zinkle, S.J., Snead, L.L., 2014. Designing Radiation Resistance in Materials for Fusion Energy. Ann. Rev. Mater. Res. 44, pp. 241-267. 


\section{Figure captions}

Fig. 1. (a)-(b) Optical images of the base material along the LD/TD and ND/TD planes respectively; (110) and (100) pole figures of the (c) base material in the fine-grained centre line of the plate and (d) in the thermo-mechanical affected zone of the ODS steel welds. The scale is in multiples of random distribution. Data in (a) and (b) taken from Dawson et al. (2017).

Fig. 2. Main components of the SALSA diffractometer at the ILL, used during the neutron diffraction experiment to obtain the residual stress maps of ODS steel welds.

Fig. 3. (a) Schematic diagram of the friction stir welding process, adapted from ( $\mathrm{Su}, 2013)$; (b) ultrasound image showing the bored thermocouple holes and diagram of thermocouple positions for Weld 1; (c)-(e) temperature profiles during FSW for the three welds; (f) torque measured during welding. Lengths are in units of $\mathrm{mm}$.

Fig. 4. Optical micrographs of the top view and cross section of the three welds: a) Weld 1, b) Weld 2, c) Weld 3. Advancing side is on right hand side of the cross sections.

Fig. 5. Residual stress maps of the three ODS steel welds. Stress in units of MPa.

Fig. 6. Line scan residual stress data at a depth of $1.4 \mathrm{~mm}$ from the top surface of the welds, in the (a) longitudinal and (b) transverse orientation; (c) peak tensile residual stress and (d) peak temperature and cooling rate as a function of traverse speed during welding. The peak values are the mean of the 5 greatest values at any 5 measurement locations in each weld.

Fig. 7. Residual stress maps of Weld 2, i.e. $95 \mathrm{~mm} / \mathrm{min}$ traverse speed, at the three measured locations. Stress in units of MPa. a) shows the measurement locations in the TransverseLongitudinal cross section. 


\section{Tables}

Table 1. Chemical composition of the studied MA956 ODS steel (wt\%).

Table 2. Friction stir welding parameters in the steady state regime, together with the peak tensile residual stress along the longitudinal and traverse directions for the three ODS steel welds produced in this study. The average cooling rate has been determined between the peak temperature and $400^{\circ} \mathrm{C}$. Weld 1 used a mean value of only thermocouples $2-4$ in the calculation. Weld 2 and 3 used a mean value of both thermocouples. 